\title{
Isolation and Characterization of Arbuscular Mychorhiza Fungi from Gaharu Wood (Aquilaria spp.) Rhizosphere
}

\author{
Dian Rachma Wijayanti ${ }^{*}$, Maman Turjaman² \\ ${ }^{1}$ Faculty of Science and Technology, Binawan University, Jakarta, 13630, Indonesia \\ ${ }^{2}$ Forest Research and Development Center, Environment and Forestry Research, Development, and Innovation Agency \\ (FORDA), Ministry of Environment and Forestry, Bogor, Indonesia \\ *email: dianrachma@binawan.ac.id
}

Rekam Jejak Artikel:

Diterima : 06/08/2020

Disetujui : 22/11/2020

\begin{abstract}
In the last 30 years there have been increasing demand of agarwood. Unlimited hunting of agarwood causing it become threatened species. Aquilaria spp. is the main genus producing agarwood that considered as threathened species. Conserving Aquilaria spp. as germ plasm needs is essential against destruction. Arbuscular mycorrhizal fungi (AMF) have been used as inoculant to increase the growth of Aquilaria spp., but information about the existence of AMF in Aquilaria spp. rhizosphere has not been reported. This research was carried out with objective to identify AMF from Aquilaria spp. rhizosphere. Soil and root samples from rhizosphere of Aquilaria spp. taken from four location that is: Carita (A. malaccensis), Ciapus (A. filaria), Cifor (A. crasna \& A. malaccensis), and Bantar Kemang (A. beccariana, A. crasna, \& A. malaccensis). Roots staining was conducted with modified Phillips and Hayman procedure (1970). Soils sample was run dry wed and placed in pot culture with Pueraria javanica as the host plant. Spore was separated from pot culture using wet sieving and decanting method continued with centrifugation. The result showed the occurrences of AMF in Aquilaria spp. roots i.e. external hypha, internal hypha, coiled hypha, arbuscules, and vesicles. All AMF colony structure found in Aquilaria spp. roots show asosiation bettwen the plant and AMF. Four species of AMF were found i.e. Glomus sp.1, Glomus sp.2, Gigaspora albida, and Dentiscutata sp.

Key Words: Isolation, Arbuscule Mycorrhizae Fungi, Rhizosfer, Agarwood
\end{abstract}

\section{INTRODUCTION}

Arbuscular mycorrhizal fungus (AMF) are fungus that has mutualistic association with plant roots. Estimated arround $80 \%$ of AMF live in symbiosis with plant roots (Goss et al., 2017). AMF is grouped under the phylum Glomeromycota (Schüßler et al., 2001; Schüßler \& Walker 2010). Glomeromyota comprise of 11 families :

Diversisporaceae,

Sacculospraceae, Acaulosporaceae,

Dentiscutataceae,

Pacisporaceae,

Gigasporaceae,

Intraomatosporaceae

Dentiscutataceae,

Racocetraceae, Enthrophoraceae, Glomeraceae,

\section{Ambisporaceae,}

Archaeosporaceae,

and Paraglomeraceae

(Redecker et al., 2013). A total number of 334 species have been identified to date (SYMPLANTA, 2020).

Gaharu wood known as agarwood, eaglewood, and aloewood in trading. Gaharu wood naturally formed special aromatic resinous product, therefore it is often used as insence, perfume and traditional medicine (Sumarna, 2013). These gaharu wood product are formed by several Thymelaceae family member. Aquilaria spp. Is one of the gaharu wood main species. There are six 
Aquilaria species in Indonesia : A. beccariana, $A$. cumingiana, A. filaria, A. hirta, A. malaccensis, and A. Microcarpa. Aqularia spp. disributed in western Indonesia, Sumatra, Kalimantan, papua barat and papua new guinea (Lee \& Mohamed, 2016).

In the last 30 years gaharu wood demand is sharply increasing. These lead to higher intensity of gaharu wood hunting. Thus result in Aquilaria spp. scarceness. International Union for Conservation of Nature (IUCN) and Covention on International Trade in Endangered Species of Wild Fauna and Flora (CITES) have reported all gaharu wood species including Aquilaria spp. in the preserved list (IUCN, 2018; CITES, 2019). Therefore preserving Aquilaria spp. is an obligatory to prefent extinction.

AMF plays an important role for the plants such as in water and mineral absorption, also in increasing plant immunity against plants pathogen. The main benefit for AMF symbiotic relation is wider soil area explored by AMF extracellular mycelium. AMF mycellia is longer and thiner than root hair, making its able of reaching wider soil pore. In addition AMF innoculum has ben reported to increase plant seeds growth (Goss et al., 2017).

Despite the fact that AMF has been often used as innoculum to increase gaharu wood plant growth (Susilowati et al. 2019), information about indigenous AMF associated with Aquilaria spp. in nature is rarely observed. This paper aim to study indigenous AMF from Aquilaria spp. rizosphere.

\section{MATERIAL AND METHODS}

This study conducted at Forestry Microbiology Laboratory and Green House of forest and nature conservation research and development center, Forestry Department in Bogor. And also at Micology laboratory Bogor Agricultural University.

Soil and Roots Samples
Soil and roots samples were collected from four different sites, Carita-Serang ( $A$. malaccensis), Ciapus-Bogor (A. filaria), CiforBogor (A. crasna and A. malaccensis), and Bantar Kemang-Bogor (A. beccariana, A. crasna, and $A$. malaccensis). One $\mathrm{Kg}$ soil sample were collected in arround 0-20 $\mathrm{cm}$ depth using plastic bag. Soil sample were immediately air dried for culture. Roots sample were cleaned and soaked in formalin actic acid alcohol (FAA) for fixation. FAA was made by mixing $13 \mathrm{ml}$ formalin, $5 \mathrm{ml}$ acetic acid (glacial) and $200 \mathrm{ml}$ ethyl alcohol.

\section{Root Staining}

After fixation Aquilaria spp. roots then cut in to twenty small pieces one $\mathrm{cm}$ each. The roots are stained using modified Phillips and Hayman staining method (1970). Roots were subjected to bleaching in a solution of $\mathrm{KOH} 10 \%$ for 5-7 days. Every day $\mathrm{KOH}$ solution is replaced with the new one until roots are cleared. Browning of the solution is an indication of the clearing process. Cleared roots then washed with water and soaked in $\mathrm{HCl} 2 \%$ overnight. To minimize over colored roots, Roots were stained with $0.05 \%$ trypan blue overnight then transferred in to glycerol acid solution. Stained roots were observed for AMF internal structure under light microscope with 100400 magnification. Infected root by AMF are known by the structure of AMF: vesicles, arbuscules, and hyphae on roots.

\section{Pot Cultures}

Rhizosphere soil sample were applied for three pot cultures. Pots were filled with sterilized zeolite and air dried rhizosphere soil sample, arranged in layer inside $200 \mathrm{~g}$ pots. The first layer was $50 \mathrm{~g}$ zeolite, following $100 \mathrm{~g}$ rhizosphere soil sample, and $50 \mathrm{~g}$ zeolite as the last layer. Once culture media ready, pots were planted with two weeks old Pueraria javanica as host plants. 
Pot cultures grown in a greenhouse for three months to initiate AMF spore production. Three months old pot cultures were left to dry undisturbed within three weeks. After three weeks AMF spores were isolated and identified.

\section{Spore Isolation}

AMF spore were isolated by wet sieving technique followed by centrifugation method (Brundrett et al., 1996). Culture media mixed thoroughly until homogenous. Afterwards $100 \mathrm{~g}$ of culture media mixed in $1000 \mathrm{ml}$ water, leave it still for a few second, and then sieved with layered sieving from $425 \mu \mathrm{m}, 250 \mu \mathrm{m}$, and $38 \mu \mathrm{m}$. Soil left on $250 \mu \mathrm{m}$ and $38 \mu \mathrm{m}$ pore washed with water, mixed together and centrifuged at $2000 \mathrm{rpm}$ for three minutes. Pellet then added with $50 \%$ sucrose solution and mixed. Subsequently, pellet-sucrose solution centrifuged at $1000 \mathrm{rpm}$ for 60 seconds. Supernatant sieved with $38 \mu \mathrm{m}$ pore and washed with water. Spores were analyzed under compound microscope and light microscope.

\section{Spore Identification}

Spore identification was done manually by making permanent slides. Slides were made by using mounting media polyvinyl alcohol-lactic acid-glycerol (PVLG) and some of the slides were added with Melzer's reagent. Identification was done by sporulation structure and subcellular spore structure. Spore wall colour was described based on percentage of cyan blue, red magenta, yellow and black colour, known as C-M-Y-K colour chart (INVAM 2017a).

\section{RESULTS AND DISCUSSION}

Stained roots showed AMF infection on Aquilaria spp. These roots are from Bantar Kemang, Carita, Ciapus, and Cifor. AMF infection structures were external hyphae, internal hyphae, coiled hyphae, arbuscules and vesicule (Picture 1). All of these AMF infection structure were present in all Aquilaria spp. observed roots.
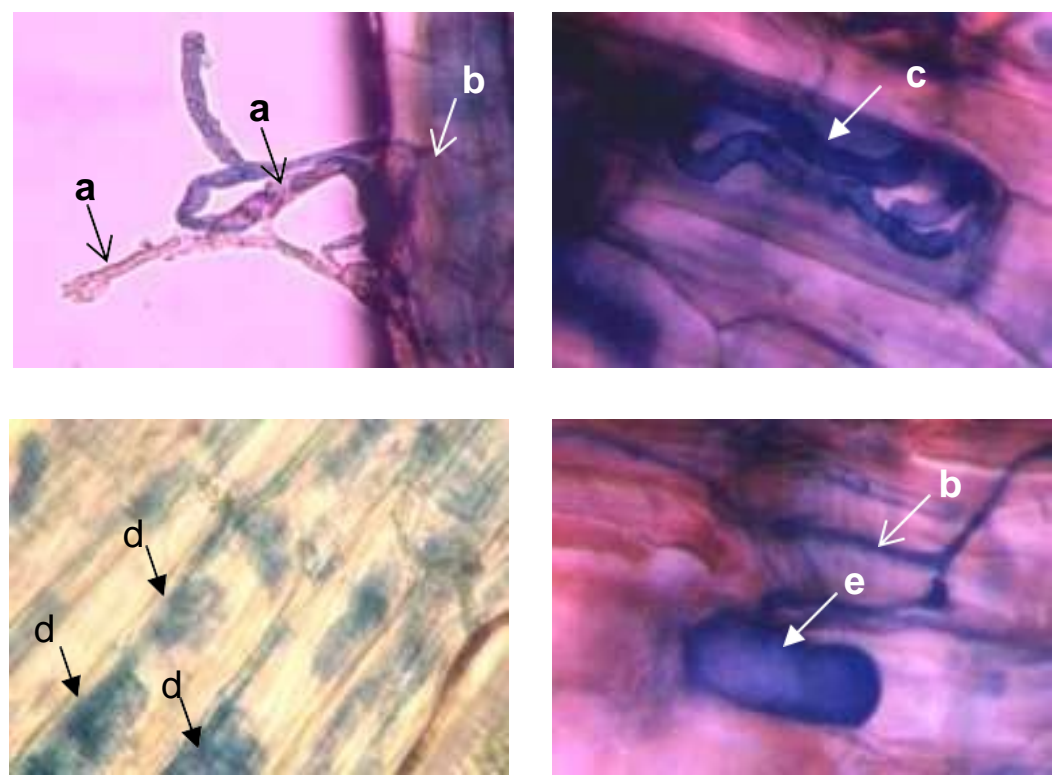

Picture 1. AMF infection on roots : a. external hyphae, b. internal hyphae, c. coiled hyphae, d. arbuscule hyphae, e. vesicles

All of Aquilaria spp. observed roots showed AMF infection structure on root cells. This means there are symbiotic association of AMF and
Aquilaria spp. plants. AMF roots infection structure observed were: external hyphae, internal hyphae, coiled hyphae, arbuscules, and vesicles. 
External and internal hyphae are present in all AMF genus. While coiled hyphae is present in Acaulospora, Archaeospora, Entrophospora, Gigaspora, \& Scutellospora. Moreover, in Glomus coiled hyphae is rarely present except in hyphae entry point on root. Arbuscules present in all AMF genus. Vesicles present in all AMF genus, except in Gigaspora and Scutellospora (Souza 2015).

Spore collected and characterized from Aquilaria spp. rhizosphere were three AMF genus: Glomus, Gigaspora and Dentiscutata. Further identification showed Glomus sp.1, Glomus sp.2 and Gigaspora albida.

\section{Glomus sp.1}

Spore colour is red brown $(0-20-80-0)$ to dark brown (20-80-100-0), subglobose to oval, 80,5-(77,62)-94.35 $\mu \mathrm{m}$ in diameter. Spore wall produce red to brown colour in PVLG and darker colour in Melze's reagent. The outer layer has a smooth surface with no ornamentation. The spore wall consists only one layer (Picture 2a), All layers in cell wall originated from subtending hypal wall (Picture 2b), 3.33-(5,43)-7.77 $\mu \mathrm{m}$ thick. Flexible germinall wall is absent. Spore wall ended at the same point where subtending hypha attached (Picture 2c). Subtending hypha is 2.22-(3,60)-5.55 $\mu \mathrm{m}$ thick and 5.55-(10,22)-23.31 $\mu \mathrm{m}$ in diameter. It consists of two wall layers that are a continuation of the spore wall. It has the same colour as the spore wall and becomes thicker when continously forming the spore wall.

Glomus sp.1 spore isolated from various soil sample and host plants It is originated from Bantar kemang (A. malaccensis), Carita (A. malaccensis), Ciapus (A. filaria), \& Cifor (A. crasna and $A$. malaccensis).
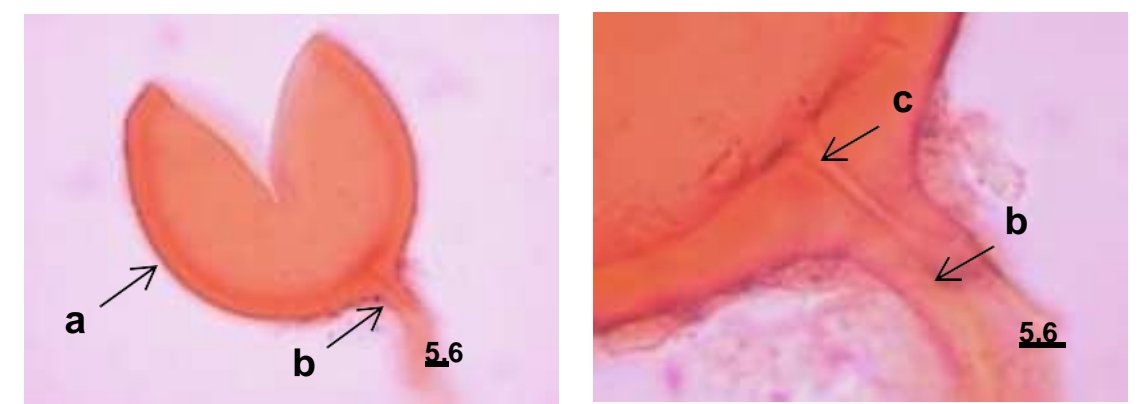

Picture 2 Glomus sp. 1 spore from A. Malaccensis rhizosphere, Carita: a. broken spore, b. subtending hyphae, c. pore

\section{Glomus sp. 2}

Spore is hyalin (0-0-5-0) to yellow 0-10-60$0)$, globose, subglobose to oblong shape, 51.06$(76,59)-115 \mu \mathrm{m}$ in diameter. Spore cell wall produce hyalin to yellow colour in PVLG and darker yellow in Melzer's reagent (Picture 3a). Spore cell wall surface is smooth with no ornamentation. Spore consists of one cell wall, all layers in cell wall originated from subtending hyphal wall (Picture 3b), spore cell wall is 1.11$(2,56)-4.44 \mu \mathrm{m}$ in diameter. Flexible germinal wall is absent. Spore cell wall ended with a pore (Picture 3c) in subtending hyphae attachment point. Subtending hyphae has the same colour as the spore wall. It is 1.11-(4,92)-6.66 $\mu \mathrm{m}$, in diameter and 1.11-(1,51)-3.33 $\mu \mathrm{m}$ thick, it gets thicker towards the spore cell wall.

Glomus sp.2 spore isolated from various soil sample and host plants. It is originated from dari Bantar kemang (A. beccariana, A. crasna, and A. malaccensis), Carita (A. malaccensis), and Cifor (A. crasna \& A. malaccensis). 

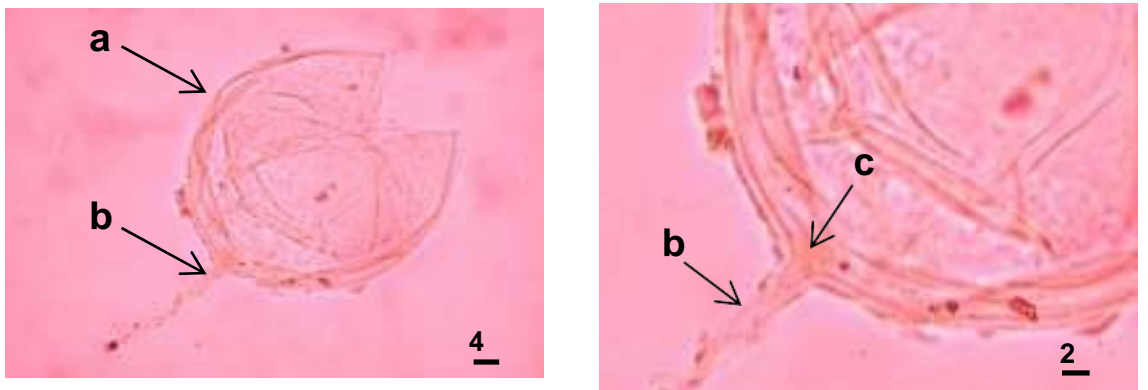

Picture 3. Glomus sp. 2 spore from A. Malaccensis rhizosphere, Bantar kemang: a. broken spore, b. subtending hyphae, c. pore

The Glomus genus collected has the same description with the previous studies (Souza 2015; Gerdemann and Trappe 1974). Spore has only one type of cell wall that is spore wall. Spore wall produce red to brown colour in PVLG and produce darker colour in Melzer's reagent. Spore wall surface is smooth without ornamentation. There is only one spore wall, generaly undergo thickening, all layers in the spore wall originated from subtending hypae wall. Spore wall ended at the pore where subtending hyphae attached.

\section{Gigaspora albida}

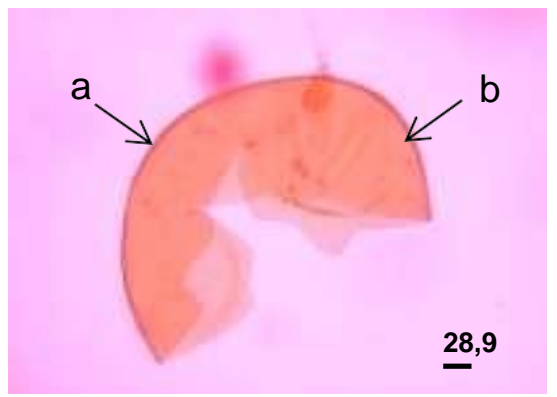

Spore produce yellow colour (0-10-60-0) in PVLG and light brown (0-30-60-0) in Melzer's reagent, globose to subglobose in shape, 260-(265)$270 \mu \mathrm{m}$ in diameter. Spore has two cell walls. The outer cell wall varied in thicknes, colour, and it attached to the second layer, spore cell wall is 3.33$(3,89)-5.55 \mu \mathrm{m}$ thick. Flexible germinall wall is absent (Picture 4a). Both of the spore wall have a smooth surface (Picture 4b). Suspensor is attached on the surface of outer spore wall (Picture 4c), has the same colourwith spore wall, 22.2-(30,53)$38.85 \mu \mathrm{m}$ in diameter, $1.11 \mu \mathrm{m}$ thick. Spore isolated from Ciapus (A. filaria).

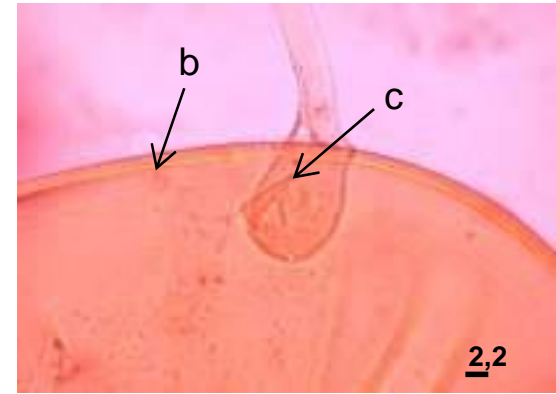

Picture 4. Gigaspora albida spore from A. filaria rhizosphere, Ciapus: a. broken spore, b. spore wall, c. Suspensor

The isolated Gigaspora albida spore has simillar description which reported by INVAM (2017b). Spore size is $260-270 \mu \mathrm{m}$ while INVAM (2017b) reported 200-280 $\mu \mathrm{m}$ spore size. Spore wall produce the same colour yellow (0-10-60-0) in PVLG as reported by INVAM (2017b). It produce darker colour in Melzer's reagent. Other simillar descriptions are there are no flexibel geminall walls formed, suspensor attaches on the outer spore wall and it has the same colour as the spore (0-10-60-0), hyphal wall consists of two wall layers resembling spore wall and has the same 
colour as the spore. Suspensor is 22.2-(30,53)$38.85 \mu \mathrm{m}$ in diameter, simillar to INVAM (2017b) report where diameter is arround $41-32 \mu \mathrm{m}$.

\section{Dentiscutata sp.1}

Spore has dark brown colour (40-80-8010) to darker brown (80-80-70-0), globose to subglobose in shape, $340 \mu \mathrm{m}$ in diameter. Spore wall produce dark brown colour in PVLG and doesn't chage its colour in Melzer's reagent. Spore wall surface has ornamentation. Spore has spore wall (Picture 5a) consists of two types of wall. The first wall varies in colour, has ornamentation and some times attaches with the second layer (Picture 5c), overall $3.33 \mu \mathrm{m}$ thick, ornament size 6.66$(13,48)-29.97 \mu \mathrm{m}$. Spore has one to two hyalin germinal flexible wall (Picture 5d) that is absent in Gigaspora and Glomus. Two germinal flexibel wall may attached as one wall. Germinal flexible walls surfaces are smooth. Suspensor attaches on the oiuter spore wall surface (Picture 5e), it has brown colour (0-60-70-10), $38.85 \mu \mathrm{m}$ in diameter, 1.11-

$2.22 \mu \mathrm{m}$ thick and it's thicker towards spore wall. Spore isolated from Carita (A. malaccensis).
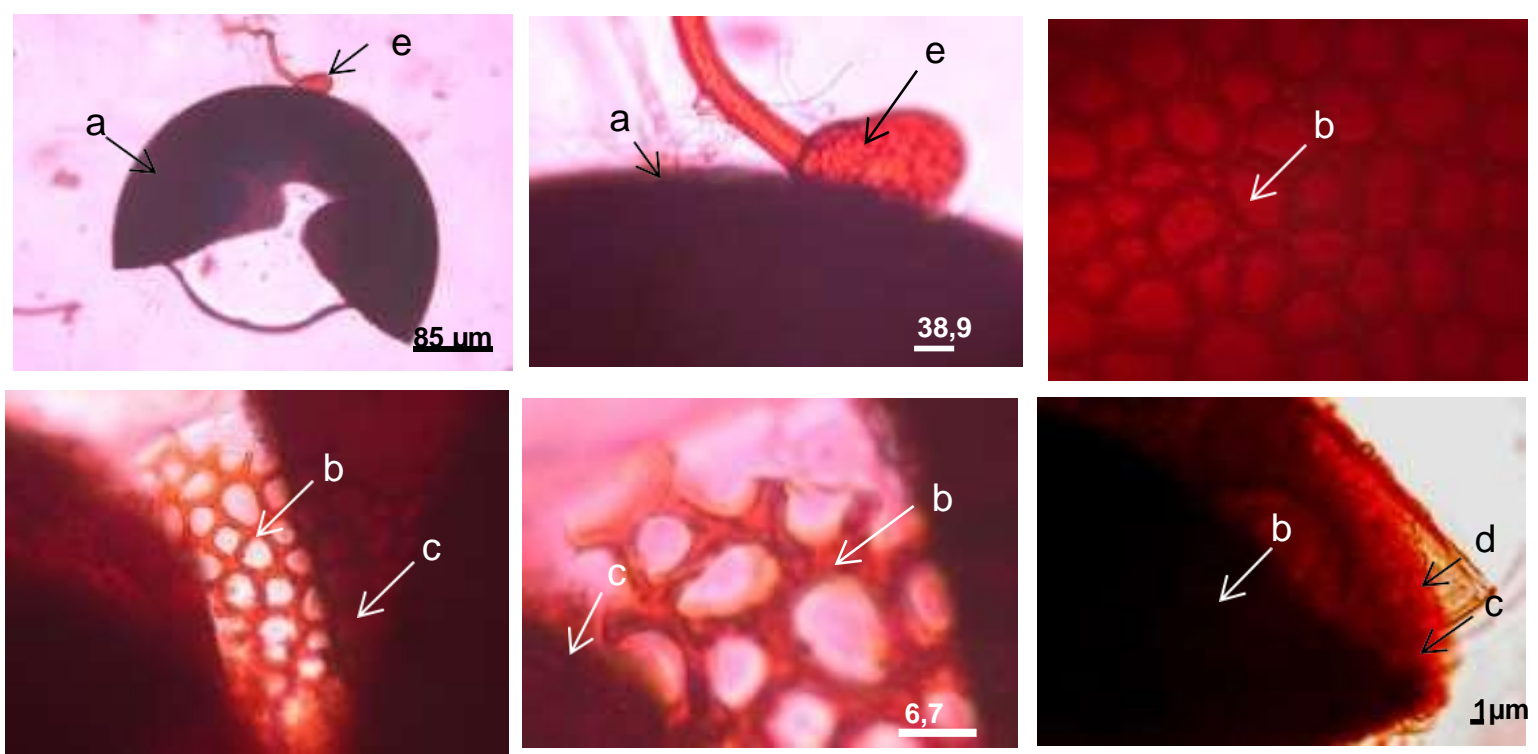

Picture 5 Dentiscutata sp. 1 spore from A. malaccensis rhsicosphere, Carita:

a. broken spore, b. the first spore wall with ornamentation,

c. the second spore wall, d. flexible germinal walll, e. suspensor

Dentiscutata spore observed is simillar with genus Dentiscutata described by Oehl at al. (2008). Spore has two spore walls, the outer spore wall and the second spore wall that might attached as one spore wall. Spore wall has ornamentation simillar to Dentiscutata sp. spore reported by Khade (2010) and INVAM (2017c; 2017d). Spore has one to two hyalin flexible germinal walls. It has suspensor that attached on the outer surface spore wall (Khade, 2010; INVAM, 2017c; INVAM, 2017d).
Spore distribution varies for each characterized spore. Glomus sp. 1 present in almost all sampling area except in A. beccariana and $A$. crasna rhizosphere from Bantar Kemang. Glomus sp. 2 isolated from all sampling area, except in $A$. filaria rhizosphere from Ciapus. Dentiscutata sp. only present in A. malaccensis rhizosphere from Carita. AMF diversity is related with plant species diversity. As reported by earlier studies that plant species diversity, types of soil, and environmental condition difference may result in different AMF 
species diversity (Muryati et al., 2016; Stürmer et al., 2018; Kurnia et al., 2019).

\section{CONCLUSION}

Indigenous AMF structures observed were external hyphae, internal hyphae, coiled hyphae, arbuscules and vesicules. AMF spore isolated, characterized and identified from Aquilaria spp. rhizosphere were Glomus sp. 1, Glomus sp. 2, Gigaspora albida and Dentiscutata sp.

\section{Acknowledgment}

We thank Agustin Wydia Gunawan for suggestions and discussions during research, also for reviewing the manuscript (Research Center, Department of Biology, IPB University).

\section{REFERENCE}

Brundrett M, Bougher N, Dell B, Grove T, Malajczuk N. 1996. Working with mycorrhizas in forestry and agriculture.Western Australia : CSIRO Centre for Mediterranian Agricultural Research : 141-157.

CITES. 2019. Cites appendices I,II and III. Tersedia pada: https://cites.org/ sites/default/files/eng/app/2019/E-Appendices2019-11-26.pdf [Diakses 23 Mei 2020].

Gerdemann JW, Trappe JM. 1974. The Endogonaceae in the Pacififi c Northwest. Mycol Memoir : 5:1-76

Goss MJ, Cardavo M, Brito I. 2017. Functional Diversity of Mycorrhiza and Sustainable Agriculture. Academic Press. United Kingdom.

IUCN. 2018. Iucn redlist. Tersedia pada: https://www.iucnredlist.org/search: Aquilatia spp, [Diakses 23 Mei 2020].

INVAM. 2017a. Species Descriptions from Reference Cultures. Tersedia pada: http://fungi.invam.wvu.edu/the-fungi/speciesdescriptions.html [Diakses 02 Juni 2020].

INVAM. 2017b. Gigaspora albida (reference accession BR214). Tersedia pada: http://fungi.invam.wvu.edu/thefungi/classification/gigasporaceae/gigaspora/al bida.html [Diakses 05 Juni 2020].
INVAM. 2017c. Dentiscutata nigra (reference accession NC182). Tersedia pada: http://fungi.invam.wvu.edu/the-

fungi/classification/gigasporaceae/dentiscutata/ nigra.html [Diakses 22 Mei 2020].

INVAM. 2017d. Dentiscutata reticulata (reference accession CL202). Tersedia pada http://fungi.invam.wvu.edu/thefungi/classification/gigasporaceae/dentiscutata/ reticulata.html [Diakses 09 Juni 2020].

Khade SW. 2010 - Dentiscutata nigerita - a new species of arbuscular mycorrhizal fungi from India. Mycosphere 1(3), 241-247.

Kurnia, Gusmiati, Larekeng SH. 2019. Identifikasi dan Karakterisasi Mikoriza Pada Tegakan Nyatoh (Palaquium sp.). Jurnal Perennial, 15(1): 51-57.

Lee SY, Mohamed R. 2016. Chapter 1: The Origin and Domestication of Aquilaria, an Important Agarwood-Producing Genus. In: Mohamed, R. (editor) Agarwood: Science Behind the Fragrance. Singapore: Springer.

Muryati S, Mansur I, Budi SW. 2016. Keanekaragaman Fungi Mikoriza Arbuskula (Fma) Pada Rhizosfer Desmodium spp. Asal Pt. Cibaliung Sumberdaya, Banten. Jurnal Silvikultur Tropika 07(3) : 188-197.

Oehl F, Souza F, Sieverding E. 2008. Revision of Scutellospora and description of fi ve new genera and three new families in the arbuscular mycorrhiza forming Glomeromycetes. Mycotaxon 106 : 311-360

Phillps JM, Hayman DS. 1970. Improved procedures for staining roots and staining parasitic and vesicular-arbuscular mycorrhizal fungi for rapid assessment of infection. Trans Br Mycol Soc 55(1) : 158-161.

Redecker D, Schüßler A, Stockinger H, Stürmer SL, Morton JB. 2013. An evidence-based consensus for the classification of arbuscular mycorrhizal fungi (Glomeromycota). Mycorrhiza 23 : 515-531.

Schüßler A, Schwarzott D, Walker C. 2001. A new fungal phylum, the Glomeromycota: phylogeny and evolution. Mycol Res 105(12) : 1413-1421

Schüßler A, Walker C (2010) The Glomeromycota. A species list with new families and new genera. Arthur Schüßler \& Christopher 
Walker, Gloucester. Tersedia pada: http://www.amf-phylogeny.com/

Schuessler\&Walker2010_Glomeromycota.pdf [Diakses 22 Mei 2020].

Souza T. 2015. Handbook of Arbuscular Mycorrhizal Fungi. Switzerland: Springer.

Stürmer SL, Bever JD, Morton JB. 2018. Biogeography of arbuscular mycorrhizal fungi (Glomeromycota): a phylogenetic perspective on species distribution patterns. Mycorrhiza. $28: 587-603$.
Sumarna. Y. 2013. Budidaya dan Bisnis Gaharu. Jakarta. Penerbit: PenebarSwadaya

Susilowati E, Riniarti M, Rini MV. Asosiasi Glomus sp. dan Gigaspora margrita pada bbit Aquilaria malacensis. Menara Perkebunan 87(2) :104-110

SYMPLANTA. 2020. Glomerpmycota Species List. Tersedia pada: http://www.amfphylogeny.com/amphylo_species.html [Diakses 23 Mei 2020]. 